\title{
The Impact of Environment Concern and Attitude on Green Purchasing Behavior: Gender as The Moderator
}

\author{
Grace K. Dagher \\ Lebanese American University \\ E-Mail: grace.dagher@lau.edu.lb \\ Omar Itani \\ Lebanese American University \\ E-Mail: omar.itani@lau.edu \\ Abdul Nasser Kassar \\ Lebanese American University \\ E-Mail: abdulnasser.kassar@lau.edu.lb
}

\begin{abstract}
The purpose of this study is to examine the moderating effect of gender on the relationship between environmental concern and attitude towards green purchasing behavior from a Lebanese consumer perspective. This study is based on socialization theory, which suggests that individual behavior is shaped by gender expectation in relation to the cultural context. An online questionnaire was used to collect data from Lebanese consumers with independent purchasing power. A total of 326 complete questionnaires were analyzed in this study. The moderating effect of gender was found to be significant and affect both environmental concern and attitude towards green purchasing behavior. The results of this study provide insights for both practitioners and scholars. The findings revealed that green marketers could benefit from increasing the level of environmental concern and attitude among both males and females. It is recommended that marketers, educators and policymakers understand the uniqueness of each market to promote green behavior. Future studies should examine the new social role of females and how it affects the green behavior.
\end{abstract}

Keywords: Environmental Attitude, Environmental Concern, Gender, Green Purchasing Behavior, ECEA 


\section{INTRODUCTION}

Environmental awareness has increased with the recent growth in interest about topics such as the greenhouse effect, ozone depletion and acid rain (Walker, 2000). "Green" is a synonym for "environmentally friendly, environmentally responsible and eco-friendly (Manakotla \& Jauhari, 2007; Pizam, 2009). Green as vision is a reality that needs more functional understanding and that helps marketers to design marketing strategies that meet the needs of green consumers (D'Souza, 2004). Because of the growth in green consumer segments of the markets, marketers are considering green consumers as their target segment (Mostafa, 2007). According to McEachern and McClean (2002), green consumerism is a complex concept that includes decreasing of pollution, environmental preservation and sustainable use of nonrenewable resources. Concerns over environmental humiliation have been increasing over the past few decades (Chan \& Lam, 2002). People have become more environmentally aware after recognizing how serious ecological problems are (Han, Hsu \& Lee, 2009). In the past decade, consumers' sensitivity toward their environment has skyrocketed in response to the need for ending and even reversing the damaging outcome of human behavior on the environment (Leonidou, Leonidou \& Kvasova, 2010). Follows and Jobber (2000) suggested that environmental consciousness can affect consumer behavior. Recently, consumers have become more likely to express their environmental concerns by purchasing environmentally friendly goods and services (Fisher, Bashyal \& Bachman, 2012; Makeower, 2009; do Paço \& Raposo, 2009). Customers can express their concern about the ethical and environmental behavior of businesses through ethical purchasing and green buying (De Pelsmacker et al., 2005). Organizations which are concerned about the environment seek to produce more green goods and services in order to satisfy such demands from customers and society at large (Soonthonsmai, 2007).

Unlike the West, consumers in the Arab and Asian Western Countries are just at the stage of green awakening (Mostafa, 2007). Culture has long been considered as one of the factors behind differences in individual behavior, leading to different systems of values and individual behavior between men and women. The difference in environmental development across cultures makes cross-cultural studies important for the improvement of green marketing and green legislation, which in return could facilitate the implementation of green strategies in the real world (Chan \& Lam, 2002). Mostafa (2007) suggested that now is the right time for consumer research examining the effect of gender differences on green purchasing behavior in the Arab/Non-Western context. Studies examinations of differences in gender on 
environmental values and perception are very limited (Wehrmeyer \& McNeil, 2000). The absence of market information about foreign markets is always a major obstacle to the successful international expansion of green products, as claimed by international green marketers (Gurau \& Ranchhod, 2005). So the need to understand the influence of gender in each market is important. As a result, gender differences in the Western context should not be directly applied to Arab contexts or any other for the reason of cultural differences.

Pressure groups, wider media coverage and more stringent legislation are considered to be major factors that led to the increase in environmental behaviors (Aitken, 2006; Melillo \& Miller, 2006). A large stream of environmental studies has focused on the role of social and demographic factors in an effort to achieve a holistic understanding of green consumers' demographics, which in return could help better segment the green market (e.g., Anderson, Henion \& Cox, 1974; Arcury, Scollay \& Johnson, 1987; Diamantopoulos et al., 2003; Kinnear, Taylor \& Ahmed, 1974; Laroche, Bergeron, \& Barbaro-Forleo, 2001; Roberts, 1996; Van Liere \& Dunlap, 1981). Drawing on a literature review of gender studies, it is found that the main theory used to explain gender difference is socialization theory. Socialization theory suggests that the behavior of individuals is conditioned by the process of socialization, which shapes the behaviors of individuals through the gender expectations of that particular cultural context (Zelezny, Chua \& Aldrich, 2000). Females and males respond to what Schahn and Holzer (1990) called the "idealized gender representations" provided by the society. Moreover, across cultures emphasize that females are more helpful, empathetic, expressive, and nurturing, whereas men are more competitive and self-determining (Beutel \& Marini, 1995; Zelezny et al., 2000). The question that should be raised today is what about the changes that have affected the social life of women in modern society? The social role of women is becoming more similar to that of males. Lebanese females are now more likely to be independent and competitive, even with males. Due to the changing roles of men and women in the workplace and at home, there is more need to examine the gender effects on environmental attitude and behaviors (Mobley \& Kilbourne, 2013). The moderating effect of gender on factors related to green purchasing behavior should be examined because results will help us not only to differentiate between female and male tendencies but also give us a better understanding of the source of these differences.

Davidson and Freudenberg (1996) stated that gender differences in environmentalism are not universal. The process of socialization starts at a young age 
and continues into adulthood, influencing the choice of occupation and attitudes toward science and technology as well as family roles, specifically from the perspective of environmental concerns (Davidson \& Freudenburg, 1996). Rather than being a static concept, gender is a process of being shaped by sociocultural contexts (West \& Fenstermaker, 1995).

Evolutionary psychology is also suggested as a way to explain gender differences in individual behaviors (Han, Hsu \& Lee, 2009). Some scholars claim that value orientation accounts for the gender differences in environmental concern (Stern et al., 2005). Other sociobiological theories explain that the reproductive-roles of females set the context for caring for others, and position females in closer with concerns about environmental deprivation (Pettus, 1997; Mobley \& Kilbourne, 2013). Even though there are many studies investigating the influence of gender on green behavior, a consensus has not been reached (Akehurst, Afonso, \& Gonçalves, 2012). In his study, Roberts (1996) found that females achieved higher ecologically conscious consumer behavior scores (ECCB). Similarly, Loureiro, McCluskey and Mittelhammer (2002) found that females are more likely to pay more for eco-labeled apples. Furthermore, female college students ranked the environmental certification of a wooden CD rack as a more important attribute compared to other attributes, such as wood type, price and storage size, when compared to males (Anderson \& Hansen, 2004). On the other hand, recent studies claimed it is still unclear whether females or males are more environmental motivated (Mobley \& Kilbourne, 2013; Xiao \& Hong, 2010).

The need to study the moderating effect of gender on the proposed relationship is what motivates this study. In this article, we will examine the moderating effect of gender on green purchasing behavior. Socio-demographic factors have been identified as possible moderators in the relationship between attitudes and behaviors (Ajzen \& Fishbein, 1980; Barron \& Kenny, 1986). Unlike previous studies discussed, this study will examine whether the difference in green purchasing behavior between females and males is due to the moderating effect of gender on the effects that environmental attitude and environmental concern have on green purchasing behavior. Even though we hypothesize that females are more likely to have higher levels of green purchasing behavior, we are interested in finding identifying the relationships between environmental attitude/concern and green purchasing behavior. Previous research has measured the relationships between gender and environmental attitudes or between age and environmental behavior, but this study will contribute to the green marketing theory by examining the moderating role of gender on the attitude-behavior relationship itself (Tarrant \& Cordell, 1997). This study can provide deep insights 
about the relationships that green marketing theorist should focus on to provide practical solutions for green practitioners in their marketing strategies.

Moreover, this study is conducted in a new context - the Arab context - which will add to the green marketing literature. As for the practical value of this study, this study's findings will provide guidance to advertisers and green marketers about gender differences from a non-Western country. The difference in environmental development across cultures makes cross-cultural studies highly important for the development and improvement of green marketing and legislation, which in turn could benefit the implementation of green strategies and rules in the real world (Chan \& Lam, 2002).

\section{CONCEPTUAL BACKGROUND AND HYPOTHESIS DEVELOPMENT}

The culture, religion, traditions and customs are factors behind the difference in behavior between men and women in Lebanon and the Arab World. According to the World Bank (2005), governments in the Middle East have only lately addressed gender and employment as fundamental facets of development. Even though the significant advancement in recent years concerning the elimination of discrimination between females and males and empowerment of females in the Arab World in various aspects of social life (MENA, 2007), the gender difference in behavior between Arab men and women still exists. The Arab countries are major players in the international economy, besides the great political, social and economic diversity that they reflect (Abuznaid, 2006). Thus, it is important to investigate more specifically Arab countries. According to Hutchings and Weir (2006), the family context, culture and traditions of Arab society identifies the role of Arab women. The social structure is completely associated within the Islamic religion (Kauser \& Tlaiss, 2011). Societal and cultural norms in the Arab region are considered to be extremely patriarchal with clear gender differences (Metle, 2002; Khattab, 1996; Kauser, 1995). The majority of Arab individuals are governed by Islamic religion. The primary role of Arab women, as interpreted by the traditional religion teachings, is to take care of household responsibilities (Kauser \& Tlaiss, 2011). A huge number of women in Middle Eastern countries are forced by their families to marry and have families (Kauser, 1995; Khattab, 1996). Islam as a religion and way of life influences Arabs to highly value marriage and family. The Islamic religion places emphasis on women's responsibility to their homes and their submission and deferral to the power of men. Gender stereotyping and the favoring of men over women are found in Middle Eastern culture, where nurturing is considered a role for women whereas leadership and 
management are typically reserved for men (AHDR, 2005; Jamali, Sidani \& Safieddine, 2005; MENA, 2007; Sidani, 2005). Several scholars consider that genderbased discrimination in Arab society has its roots in the family and cultural traditions of the Arab male-dominated culture (Orabi, 1999; Abdalla, 1996). To this day, gender roles have habitually been distinguished and females are expected to care.

According to Powell and Graves (2003), the gender role attitudes are related to characteristics associated with individuals in the socialization of babyhood, where women and men acquire different behaviors and attitudes related to gender. This socialization type occurs in most countries and is commonly practiced in the Middle Eastern states where the structure of society is controlled by males (Hutchings \& Weir, 2006; Barakat, 1993). Women are seen to demonstrate specific personality traits that are recognized with their gender, such as attachment, warmth, emotions and social concern (Williams \& Best, 1990; McKeen \& Burke, 1990). Lebanon is professed to be a unique country in this region due to its interaction between the Middle East and the West (Tlaiss \& Kauser, 2011). Lebanese culture combines Christian, European and Arab Non-Fundamentalists Muslim values (Neal et al., 2005). According to Tlaiss and Kauser (2010), Lebanon holds both strong cultural and religious customs in addition to modern values. The attempts toward modernization in Lebanon; however, did not bring about the desired levels of social, economic and political equality (AHDR, 2005; MENA, 2007). Accordingly, an examination of these issues from the perspective of Lebanese social, cultural and religious attachment is needed to understand the status of Lebanese women today (Tlaiss \& Kauser, 2011). With some exceptions, Lebanese women agree to play the role of housewives, a role that is encoded within Lebanese society. Tlaiss and Kauser (2011) concluded that patriarchal values stressing the nurturing role of women as moms and wives were found to be rooted very deeply in Lebanese culture.

\section{Green Purchasing Behavior}

Consumers are aware of the huge effect that their purchasing behavior has on the environment (Wahid, Rahbar \& Shyan, 2011). With the increase in environmental problems, consumers are now trying to help solve such problems through their individual behaviors. Over the last few years, the number of green consumers has increased threefold (Makeower, 2009). According to Dagher and Itani (2012, 2014), consumers are trying to help sustain their environment by demonstrating green purchasing behavior. "Green consumers are conceptualized as goal-oriented individuals and influential market actors who use their purchasing power to bring 
about social change by taking into account the public environmental consequences of their private consumption" (Moisander, 2001, p. 252). Simply put, green purchasing is the act of adding environmental criterion to other criteria such as quality and price during the making a purchase decisions (Vazifehdoust et al., 2013). Numerous studies conducted in Western countries on environmental consumption have found that women make more recurrent eco-friendly purchasing decisions compared to men (McIntyre et al., 1993; Banerjee \& McKeage, 1994). Compared to men, women also participate more in pro-environmental behaviors, in both Sweden (Widegren, 1998) and the United States (Steel, 1996). Lee (2009) concluded that adolescent females rated significantly higher than adolescent males in green purchasing behavior in China. Furthermore, Deng et al. (2006) and Snelgar (2006) found that females have more environmental values as captured by the New Ecological Paradigm developed by Dunlap et al. (2000). Females showed higher intention to use a green hotel, recommend the hotel to others, and pay premium prices for it (Han et al., 2011). Females from the United Kingdom were more likely to engage in recycling behavior than males (Diamantopoulos, 2003).

On the other hand, Ling-yee (1997) found that men in Hong Kong are more likely to search for information on green product and to purchase such products, especially health food products. Eisler et al. (2003) found that males exhibited higher environmental knowledge levels compared to females. Furthermore, Aoyogi-Usui et al. (2003) found that females are less likely to participate in environmental behavior than males. Moreover, some studies have found no relationship between gender and environmental behavior (Blankenau, Snowden \& Langan, 2008; Berenger, Corraliza \& Martin, 2005).

Hayes (2001) refers to the different results found in the studies as the "gender gap". Thus, our first hypothesis in this study is as follows:

H1: Female consumers would express higher green purchasing behavior than male consumers.

\section{Environmental Attitude}

According to Schwartz (1992), general attitudes are collections of beliefs that translate into actions regarding the object of interest. Different consumer behavior models suggest variables such as attitudes to be tested when studying environmental behavior (Fisher, Bashyal \& Bachman, 2012). Environmental attitude is generally understood as the rational judgment of people toward the value of environmental protection (Lee, 2009). Environmental attitude is acquired over time and increases 
individuals' environmental concern and protection (Widegren, 1998). Kotchen and Reiling (2000) found that attitudes are important interpreters of behavior, behavioral intention and factors that explain variations in the behavior of individuals. Many studies examined the relationship between environmental attitudes and environmental behaviors. For example, Balderjahn and Katz identified a positive relation between environmental attitude and environmental behavior (1988). Further examination of the literature, however, indicates contrary evidence as well. On the other hand, a moderating relationship between environmental attitudes and ecological behavior (Smith et al., 1994) and weak relationship (Berger \& Corbin 1992) were identified. Konrad et al. (2000) argued that due to the existing gender roles of males and females, attitudes differ significantly. Tikka et al. (2000) found that Western females express more positive environmental attitudes than Western males. Zelezny et al. (2000) reported that women have greater environmental attitudes than men across 14 different countries, including Argentina, Canada and Spain. According to Zelezny and Bailey (2006), one of explanations for the gender difference in green behavior is the socialization of gender roles. Females act more concerned toward their environment due to their biospheric orientation (Merchant, 1979), which focuses on values that accentuate the importance of the environment (Stern et al., 2005). Weigel (1983) suggests that feelings and attitudes about certain issues predisposes a person to behaving in a consistent manner toward this purpose. According to socialization theory, gender difference exerts a vital effect on attitudes in general (Beutel \& Marini, 1995; Cross \& Madson, 1997) and provides evidence that women hold a pro-social orientation (Hughes \& Tuch, 2003); however, it is unclear whether such tendencies manifest themselves equally across genders. Females with their positive attitude toward others in general, may be projected to increase positive attitudes toward the environment. Such positive attitudes act as mechanism to increase the green behavior as suggested by the literature. Thus, individuals of either gender who have a higher environmental attitude will be more engaged in real green purchasing behavior. Thus, we propose the following hypothesis:

H2: The positive relationship between environmental attitude and green purchasing behavior is moderated by gender; that is, the higher the level of environmental attitude, the higher the green purchasing behavior will be for females as compared to males. 


\section{Environmental Concern}

This is an important attribute that can represent an individual's compassion, likes and dislikes, and concern about the environment. Environmental concern ranges from very unconcerned to highly concerned, and is measured using the new environmental paradigm (Milfont \& Duckitt, 2004). Environmental concern is an important variable that impacts the decision making of consumers (Jain \& Kaur, 2004). Studies show that when consumers are highly concerned about the environment, they are more likely to evaluate the effects of their purchases on the environment (Follows \& Jobber, 2000; Nath et al., 2013). Schultz (2000) stated three factors of environmental concern: egoistic (i.e., concern for the self), altruistic (i.e., concern for others) and the biospherical. Stern and Dietz (1994) stated that these three factors are the categories of ecological value orientation, which is defined by Thompson and Barton (1994) as the motivational concern expressed for environmental issues based on the individual's conception of his or her relation to the environment. The more environmental concerns one has, the more such concerns lead to an increase in environmentally friendly purchase behaviors (Kalafatis et al., 1999; Laroche et al., 2001; Manakotla \& Jauhari, 2007). Seguin et al. (1998) found that the environmental concern factor can have a huge influence on individuals' motivation to behave in a way that can alleviate environmental problems. Kim and Choi (2005) claim that environmentally concerned consumers are more likely to buy green products than are those with less concern. Other research states that public beliefs regarding environmental concern change quickly over time (Roberts, 1996). Eagly (2013) identified that females are more likely to be concerned about others' welfare as compared to males. The base of gender differences in environmental behavior may be due to one's attention to values and information, particularly when considering the degree of concern for others, including humans, other species and the environment (Mobley \& Kilbourne, 2013). In turn, such values are the outcome of one's life experience and socialization (Dietz, Kalof, \& Stern 2002; Zelezny, Chua, \& Aldrich 2000). Zelezny et al. (2000) found that gender difference in environmental concern could begin at an early age. One study found that male students are less likely to perceive the risks affecting their environment than female students (Riechard \& Peterson, 1998). Laroche et al. (2001) found that women are more environmentally concerned and willing to pay for environmentally friendly products than men. Using national telephone interviews across the United States, Tarrant and Cordell (1997) found no moderating effect of gender on environmental concern. Females are less likely to handle concern and anxiety toward other objects (Riechard \& Peterson, 1998). From that we can argue, women are more likely to 
translate their environmental concern into behaviors that can mitigate such concerns. A higher degree of environmental concern will lead to an increase in green behavior, as suggested by the literature. In this sense, the same levels of environmental concern will lead females to higher levels of green purchasing behavior. Simply put, women are more concerned about environmental issues compared to men (Mohai, 1992). Thus, we propose the following hypothesis:

H3: The positive relationship between environmental concern and green purchasing behavior is moderated by gender; that is, the higher the level of environmental concern, the higher the green purchasing behavior will be for females compared to males.

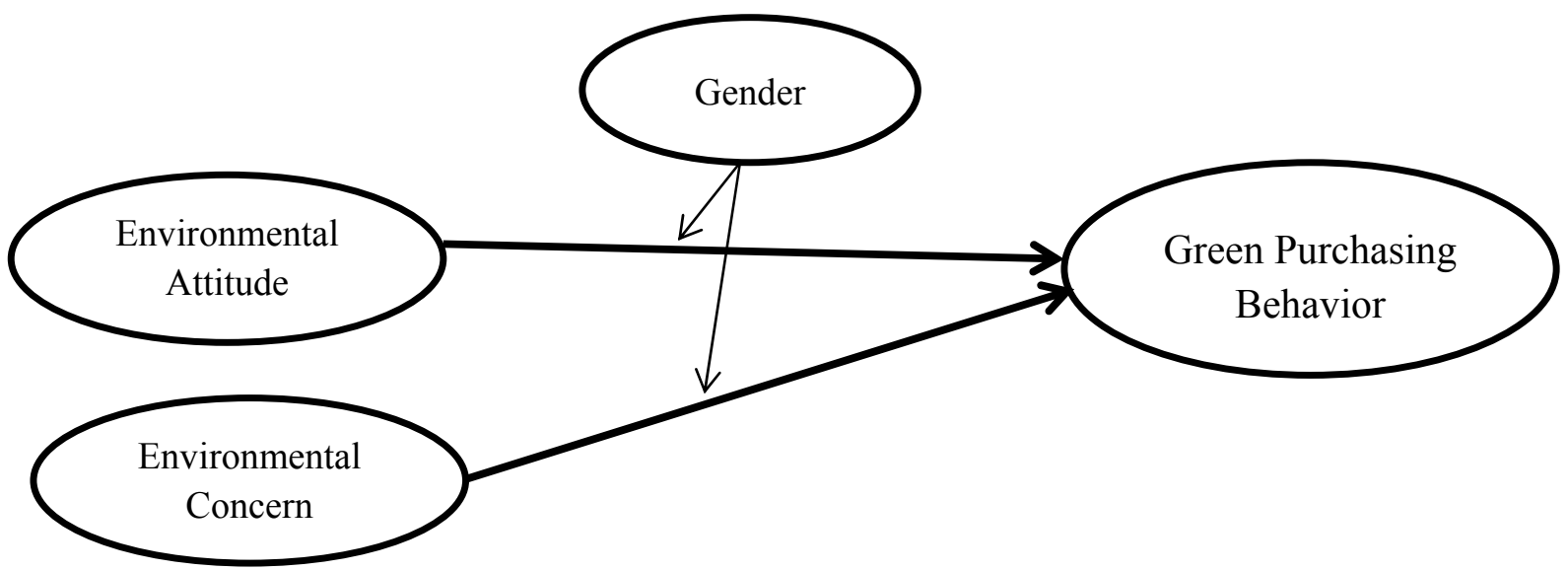

Figure 1 Conceptual Model

\section{RESEARCH METHODOLOGY AND RESULTS}

An online questionnaire was developed and used to collect data for this study. Our target was any consumer with independent purchasing power. A total of 500 questionnaires were sent, and 326 complete questionnaires were returned and analyzed, resulting in a response rate of $65 \%$. All respondents participated voluntarily. A special link was sent to all individuals in our sample via email. The questionnaire was divided into four parts: 1) environmental attitude, 2) environmental concern, 3) green purchasing behavior, and 4) demographics. To measure green purchasing behavior, environmental attitude and environmental concern were adapted from Lee (2009). All items were measured on 5-point Likert scale. Four items were used to measure green purchasing behavior: 1) When I want to buy a product, I look at the ingredients label to see if it contains things that are environmentally friendly (gpb1); 
2) I prefer green products over non-green products when their product qualities are similar (gpb2); 3) I choose to buy products that are environmentally friendly (gpb3); 4) I buy green products even if they are more expensive than the non-green alternatives (gpb4). Seven items were used to measure environmental attitude: 1) It is essential to promote green living in Lebanon (ea1); 2) I strongly agree that more environmental protection efforts are needed in Lebanon (ea2);3) It is very important to raise environmental awareness among Lebanese people (ea3); 4) Environmental protection efforts are simply a waste of money and resources (ea4); 5) Environmental protection issues are none of my business (ea5); 6) I think environmental protection is meaningless (ea6); 7) It is unwise for Lebanon to spend a vast amount of money on promoting environmental protection (ea7). Four items were used to measure environmental concern: 1) I am worried about the worsening of the quality of Lebanon's environment (ec1); 2) Lebanon's environment is my major concern (ec2); 3) I am emotionally involved in environmental protection issues in Lebanon (ec3); 4) I often think about how the environmental quality in Lebanon can be improved (ec4). All items have loaded on the corresponding factor with loadings above 0.7. According to Hair et al. (1998), it is recommended to retain loadings above 0.6 and remove all loadings below 0.3. All items loadings were above 0.6. Results of the reliability coefficient for the three factors were satisfactory (environmental attitude $\alpha=0.85$, environmental concern $\alpha=0.85$, and green purchasing behavior $\alpha=0.89$ ). Table 1 lists the correlation, reliability coefficient and average variance extracted for each factor.

Our sample was $49.7 \%$ male and $50.3 \%$ female. The age of the majority was between 20 and 30 years (57\%). More than half of the respondents were single, and $61 \%$ held a bachelor's degree, $19 \%$ held a master degree, $3 \%$ held a doctoral degree, and $4.8 \%$ held a professional degree. Table 2 presents a detailed description of our sample.

\section{Hypotheses Testing and Results}

To test hypothesis 1 , we used an independent t-test analysis. The results show that the green purchasing behavior mean for females was 2.9 compared to 2.6 for males. The t-test provides evidence that the difference between the two means is significant $(\mathrm{t}=2.68, \mathrm{p}<0.01)$; thus, $\mathrm{H} 1$ is supported. Before further analysis, multicollinearity was assessed with variance inflation factors (VIF). The results show that the VIF range was between 1 and 1.2, which is below the VIF cutoff value of 10 as recommended by Hair et al. (1998). 
To test the hypotheses $(\mathrm{H} 1 \& \mathrm{H} 2)$, we used hierarchal moderated regression analysis. Two sets of linear regression models were tested using SPSS 19 (Table 2). Model 1 regressed the dependent variable (green purchasing behavior) on the independent variables (environmental attitude, concern, gender). Model 2 regressed the dependent variable (green purchasing behavior) on the independent variables (environmental attitude, concern, gender), and also on the interactions terms between environmental attitude and gender as well as between environmental concern and gender in order to test the moderation effects of gender. As shown in Table 3, model 1 finds that environmental attitude is positively related to green purchasing behavior $(\beta=0.13, \mathrm{t}=2.48, \mathrm{p}<0.05)$. Environmental concern is positively related to green purchasing behavior $(\beta=0.42, \mathrm{t}=8.07, \mathrm{p}<0.01)$. Moreover, gender $(0=$ male, $1=$ female $)$ was positively related to green purchasing behavior $(\beta=0.19, \mathrm{t}=4.0, \mathrm{p}<0.01)$. The $\mathrm{R}^{2}$ for Model 1 is 0.245 . Model 2 was used to test the moderating impact of gender on the relationships between (1) EA and GPB, (2) EC and GPB. Results show that the corresponding interactions coefficient were statistically significant $\left(\beta_{\mathrm{EAxG}}=-0.086\right.$, $\mathrm{t}=1.67, \mathrm{p}<0.1) ;\left(\beta_{\mathrm{ECXG}}=-0.092, \mathrm{t}=1.75, \mathrm{p}<0.1\right)$, which support $\mathrm{H} 1$ and $\mathrm{H} 2$, respectively. The $\mathrm{R}^{2}$ for model 2 is .264 . Thus, $\mathrm{H} 1$ and $\mathrm{H} 2$ were supported. Graphically, the results are illustrated in Figure 2A and 2B.

Table 1 Correlations and Descriptive Statistics

\begin{tabular}{lcccc}
\hline & EA & EC & G & GPB \\
\hline Environmental Attitude (EA) & $\mathbf{0 . 8 5}$ & & & \\
\hline Environmental concern (EC) & $0.324^{*}$ & $\mathbf{0 . 8 5}$ & & \\
\hline Gender (G) & 0.049 & $-0.127^{* *}$ & - & \\
\hline Green Purchasing Behavior (GPB) & $0.273^{*}$ & $0.434^{*}$ & $0.147^{*}$ & $\mathbf{0 . 8 9}$ \\
\hline Mean & 2.10 & 2.20 & - & 2.75 \\
\hline Standard Deviation & 0.42 & 0.72 & - & 0.92 \\
\hline Average variance Extracted (AVE) & $\mathbf{0 . 8 4}$ & $\mathbf{0 . 6 9}$ & - & $\mathbf{0 . 7 5}$ \\
\hline
\end{tabular}

$*$ coefficients are significant at a $=0.01, * *$ coefficients are significant at $\mathrm{a}=0.05$; Cronbach's are on the diagonal written in Italic and bold. 
Table 2 Demographic Characteristics

\begin{tabular}{lc|lc}
\hline Gender & Percent & \multicolumn{1}{|c}{ Education } & Percent \\
\hline Male & 49.7 & High School & 5.7 \\
Female & 50.3 & Technical School & 3.8 \\
Marital Status & & Bachelor degree & 61.3 \\
Single & 54.6 & Master's degree & 19 \\
In a relationship & 22.7 & Doctoral degree & 3.2 \\
Married for the first time & 19.6 & Professional degree & 4.8 \\
Remarried & 0.6 & Missing & 2.2 \\
Separated & 0 & Work Experience(years) & \\
Divorced & 2.5 & None & 32.2 \\
Widowed & 0 & 1 & 11.3 \\
Age & & 2 & 9.8 \\
Less than 20 & 11.7 & 3 & 6.1 \\
20-30 & 57.1 & 4 & 5.8 \\
$31-40$ & 18.7 & 5 & 4.6 \\
$41-50$ & 8.9 & 6 or more & 30.1 \\
$51-60$ & 3.1 & & \\
Older than 61 & 0.6 & & \\
\hline
\end{tabular}

Table 3 Regression Analysis

\begin{tabular}{ccccccc}
\hline \multicolumn{2}{c}{ Model 1 } & \multicolumn{3}{c}{ Model 2 } \\
& $\beta$ & t-value & $\mathrm{R}^{2}$ & $\beta$ & t-value & $\mathrm{R}^{2}$ \\
\cline { 2 - 7 } EA & $0.13^{* *}$ & 2.48 & 0.245 & & & \\
EC & $0.42^{*}$ & 8.07 & & & & \\
G & $0.19^{*}$ & 4.0 & & & & \\
EA & & & $0.11^{* *}$ & 2.13 & 0.264 \\
EC & & & $0.39^{*}$ & 7.40 & \\
G & & & $0.19^{*}$ & 3.94 & \\
EAxG & & & $-0.085^{* * *}$ & 1.67 & \\
ECxG & & & $-0.092^{* * *}$ & 1.75 & \\
\hline
\end{tabular}

$*$ coefficients are significant at $\boldsymbol{\alpha}=0.01, * *$ coefficients are significant at $\boldsymbol{\alpha}=0.05, * * *$ coefficients are significant at $\boldsymbol{\alpha}=0.10$. Environmental Attitude (EA), Environmental Concern (EC), Gender (G), EAxG and ECxG are interaction terms. $\mathrm{R}^{2}$ for both models are given in the table. The change in $\mathrm{R}^{2}$ is significant at $\mathrm{p}$-value $<0.01$. 
A. Environmental Concern to Green Purchasing Behavior: moderating role of Gender

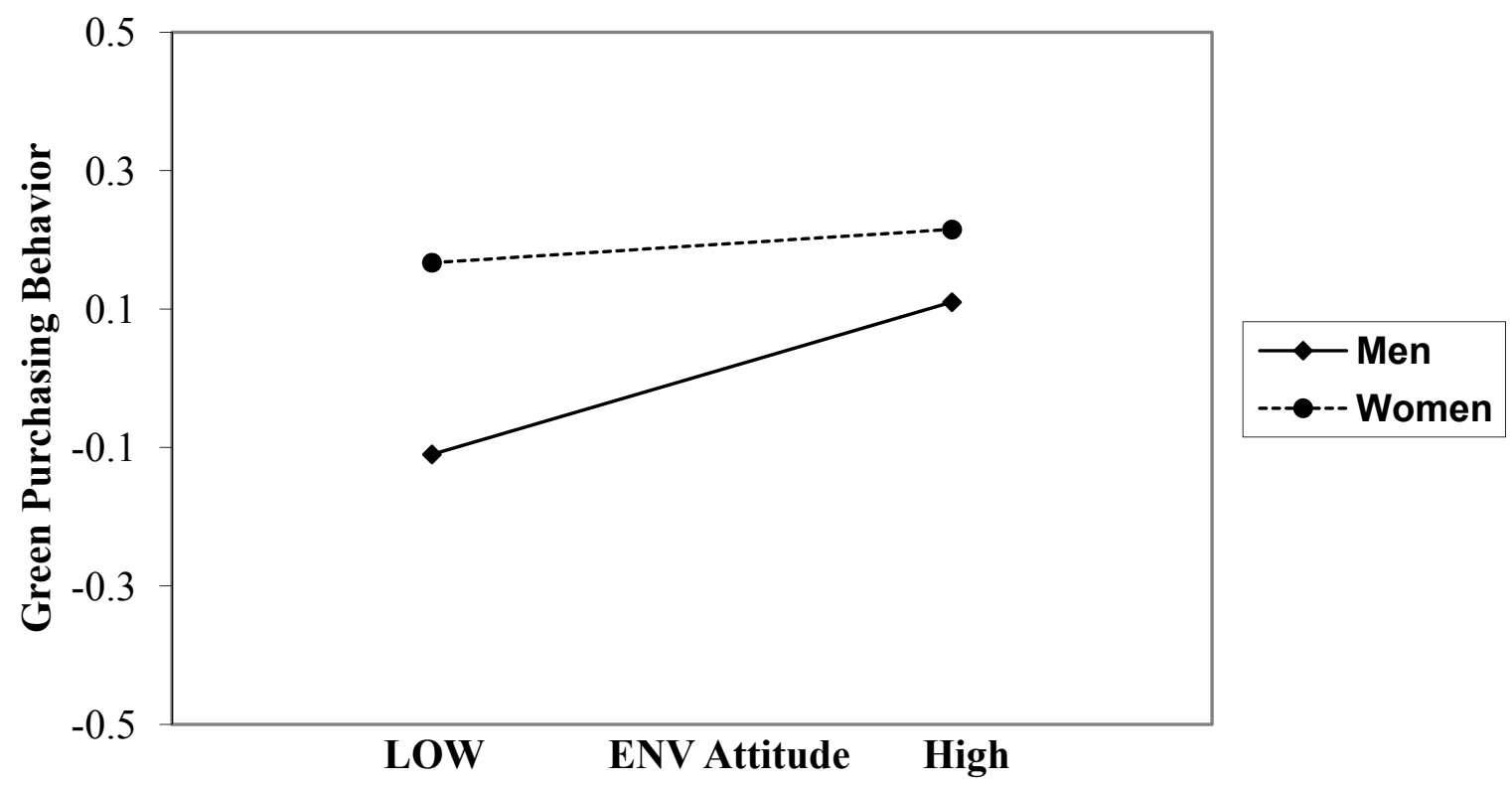

B. Environmental Attitude and Green Purchasing Behavior: moderating role of Gender

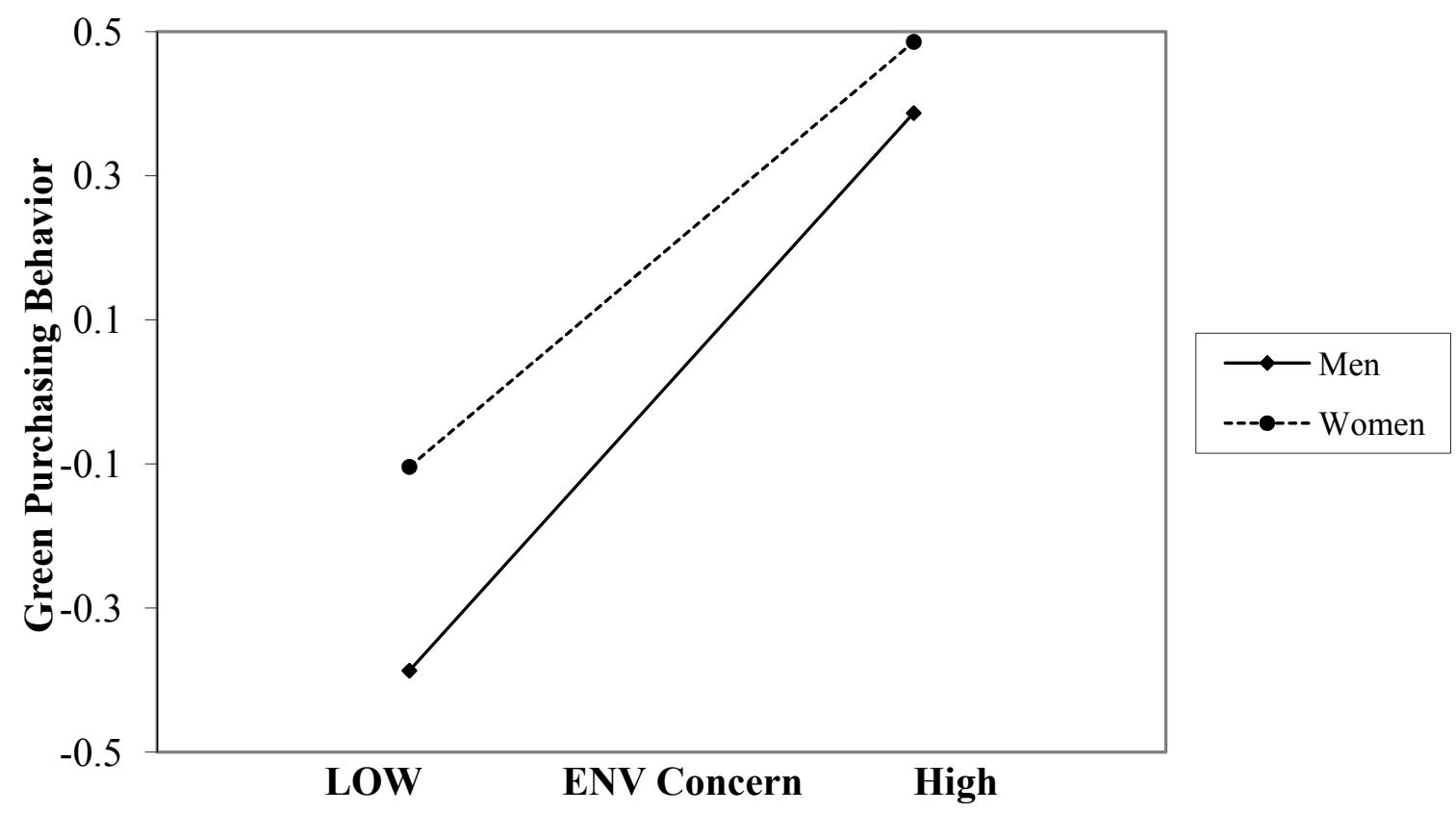

Figure 2 Moderating Effect of Gender

Note: Figure2 show standardized values 


\section{CONCLUSION}

As Lebanon is an Arab country, the results of this study will add to the green marketing literature from a non-Western country perspective. Konrad et al. (2000) argued that because of the existing gender role between males and females, attitudes differ significantly. Environmental attitude is generally understood as the rational judgment of people toward the value of environmental protection (Lee, 2009). The results of this study highlight the importance and necessity of investigating not only gender differences but the moderating effect of gender on the relationship between environmental attitude and environmental concern toward green purchasing behavior. The results of the moderating effects of gender on the proposed relationships provides evidence that the difference in environmental attitude and environmental concern between genders has different influence on green purchasing behavior at high vs. low levels of environmental concern and environmental attitude. At higher levels of environmental attitude and concern, males and females are likely to share relatively similar levels of green purchasing behavior; however, at lower levels, green purchasing behavior differs significantly. The results indicated that females in this male-dominant culture are more taking green actions than the males. The results indicated that the relationship between environmental attitude and green purchasing behavior is strengthened more by females rather than by males. Tikka et al. (2000) found that Western females express more positive environmental attitudes than Western males. Zelezny et al. (2000) reported that women have greater environmental attitudes than men across different countries. As for the environmental concern factor, the results indicated that the relationship with green purchasing behavior is strengthened by females more than males, which led to an increase in environmentally friendly purchase behaviors (Kalafatis et al., 1999; Manakotla \& Jauhari, 2007; Laroche et al., 2001). Laroche et al. (2001) found that women are more environmentally concerned and willing to pay for environmentally friendly products than men. This is also in line with the socialization theory argument that women have a stronger "ethic to care" and are more compassionate and nurturing (Beutel \& Marini, 1995). Furthermore, caring is an important value that is initiated by females in Lebanon and in the Arab world, which creates an expectation of this type of behavior from Arab females. According to Wrong (1961), socialization is the transmission of cultural norms, socialization is the transmission of cultural norms. Arab culture places responsibility on females when it comes to family and home. Since the Arab female is responsible for raising the children and transmiting the cultural norms, they tend to initiate environmental concern, attitude and behavior in the new generation. The 
results of this study will provide insights and guidelines from a Lebanese consumer perspective to both practitioners and scholars.

\section{Managerial Implications}

According to Lim et al. (2013), now is the time to improve green marketing strategies since it is crucial for promoting green products. Understanding the uniqueness of each market will help to market the products in a more effective way and can influence the target market and ultimately the target consumer. The results show that practitioners can increase the size of the green market when they focus on increasing the environmental attitude and concern among males and females. The results show that high levels of environmental concern and attitude will increase the level of green purchasing. Our findings show that females should not be the only targets for green marketers. Marketing practitioners should target both females and males. When both males and females share higher levels of environmental concern and attitudes, they might have similar green behaviors. Figure 1 ( $a \& b$ ) shows that the difference in green purchasing behavior between males and females is minimized at higher levels of environmental attitude and concern. Thus, green products could increase their market share if the firms' marketing strategies were to focus on increasing consumers' attitude and concern about their environment among both genders.

Market practitioners should integrate different marketing tools to increase environmental attitude and concern, due to the significant positive effect that such factors have on green behavior. To increase environmental concern, marketers should describe the hazardous situation that our environment is facing. On the other hand, other communication frames that focus on the benefits of better environments on our well-being and health could increase positive attitudes toward the environment. Green brands should communicate not only their positive effects on the environment but also general information about environmental opportunities and problem that consumers may be engaging in when buying such brands. So, it is very important to focus on improving the literacy of the different media to raise awareness among consumers and improve environmental concern and attitude, leading to increased green behavior in the future.

Finally, as mentioned in the literature review, the attitude of individuals is developed during childhood, so we must direct our attention to the role of our educational institutions and their curriculum. Academic institutions at all levels schools and universities - need to update their curriculum to address environmental 
awareness and concerns (Nath et al., 2013; Jabbour, 2009; Kasturi, 2011) in order to develop an environmental attitude that will lead to green behavior both now and in the future.

\section{LIMITATIONS AND FUTURE STUDIES}

As with any study, this study has its limitations. The first limitation is the small sample size. Thus, future studies should increase the sample size and collect data from different Arab countries so that the results can be more generalizable. Moreover, our study examined the green purchasing behavior in general and did not consider specific kinds of products or behaviors. Research is needed to examine more specific behaviors, such as electricity savings and reuse of plastic bags. Such research can provide more detailed information about the gender difference in green behaviors. Moreover, the data is self-reported, so future studies should collect data while the purchasing behavior is taking place. For example, future data can be collected from consumers in a store while the purchasing transaction is taking place or at the entrance of the mall. More objective data should be collected, such as the amount of money spent on green products compared to others. In our study, we only focused on gender as one demographic variable. This constitutes another limitation to our study. Several demographic variables can be interrelated with gender, such as education and marital status, that could also affect the relationships examined in this study. In addition, the majority of respondents examined in our sample were older than twenty years. Research should focus on studying the green behavior of teenagers and children as well. Future studies can also study the effect of parents' green behavior on that of their youngsters.

Additionally, future studies should examine if there is significant difference in mean green purchasing behavior in low vs. high environmental concern/attitude. Results show that increasing the level of environmental attitude or environmental concern will lead to a reduction in the mean difference of green purchasing behavior between females and males. Further studies should examine the new social role of females (e.g., working, independent) and how such a role can affect green behavior. In this sense, it is important to state that the context under which our study took place is still male-dominant. Males are the head of the households; they are the ones with the higher purchasing power and can affect the behavior of the in-group more. Because of that, future studies should focus on the increasing males' participation in green behavior for the purchasing power they possess. 
Future research should examine the best strategies to transform consumers' environmental knowledge into more concern and positive attitude toward the environment. Arcury et al. (1987) found that males are more knowledgeable about the environment. Research should try to answer the question of how to change or transform environmental knowledge into higher levels of concern and attitude for the benefits that such factors have on green purchasing behavior. Finally, future studies should empirically examine the impact of factors such as personality type as moderating or mediating variables on the relation between environmental attitude, concern and green purchasing behavior to better understand consumer behavior.

\section{REFERENCES}

Abdalla, I. A. (1996). Attitudes towards women in the Arabian Gulf Region. Women in Management Review, 11(1), 29-39. http://dx.doi.org/10.1108/09649429610109271

Abuznaid, S. (2006). Islam and management: What can be learned? Thunderbird $\begin{array}{llll}\text { International Business } & \text { Review, } & 48 & \text { (1), }\end{array}$ http://dx.doi.org/10.1002/tie.20089

AHDR (2005). Towards the Rise of Women in the Arab World, United Nations Development Program: Regional Bureau for Arab States, National Press, Jordan. Aitken, L. (2006). Green works. Campaign (UK), 28, 26-27.

Ajzen, I., \& Fishbein, M. (1980). Understanding attitudes and predicting social. Behaviour. Englewood Cliffs, NJ: Prentice-Hall.

Akehurst, G., Afonso, C., \& Gonçalves, H. M. (2012). Re-examining green purchase behaviour and the green consumer profile: new evidences. Management Decision, 50(5), 972-988. http://dx.doi.org/10.1108/00251741211227726

Anderson, R. C., \& Hansen, E. N. (2004). Determining consumer preferences for ecolabeled forest products: an experimental approach. Journal of Forestry, 102(4), 28-32.

Anderson, T.W., Henion, K.E., \& Cox, E.P. (1974). Socially vs. ecologically concerned consumers.American Marketing Association Combined Conference Proceedings, 36, 304-311.

Aoyogi-Usui, M., Vinken, H., \& Kuribayashi, A. (2003). Pro-environmental attitudes and behaviors: An international comparison. Human Ecology Review, 10(1), $23-$ 31 . 
Arcury, T.A., Scollay, S.J., \& Johnson, T.P. (1987). Sex differences in environmental concern and knowledge: The case of acid rain. Sex Roles, 16(9-10), 463-472. http://dx.doi.org/10.1007/BF00292481

Balderjahn, I. (1988). Personality variables and environmental attitudes as predictors of ecologically responsible consumption patterns. Journal of business Research, 17(1), 51-56. http://dx.doi.org/10.1016/0148-2963(88)90022-7

Barakat, H. (1993). The Arab World: Society, culture, and state. Berkeley, CA: University of California Press.

Baron, R. M., \& Kenny, D. A. (1986). The moderator-mediator variable distinction in social psychological research: Conceptual, strategic, and statistical considerations. Journal of personality and social psychology, 51(6), 1173. http://dx.doi.org/10.1037/0022-3514.51.6.1173

Banarjee, B., \& McKeage, K. (1994). How green is my value: exploring the relationship between environmentalism and materialism. Advances in consumer research, 21(1), 147-152.

Berger, I. E., \& Corbin, R. M. (1992). Perceived consumer effectiveness and faith in others as moderators of environmentally responsible behaviors. Journal of Public Policy \& Marketing, 11(2), 79-89.

Beutel, A. M., \& Marini, M. M. (1995). Gender and values. American sociological review, 436-448.

Berenguer, J., Corraliza, J. A., \& Martin, R. (2005). Rural-urban differences in environmental concern, attitudes, and actions. European Journal of Psychological Assessment, 21(2), 128-138. http://dx.doi.org/10.1027/10155759.21.2.128

Blankenau, J., Snowden, M., \& Langan, M. (2008). Understanding environmentalism in a red, agricultural state: The impact of political party identification and place of residence. Sociological Spectrum, 28(1), 55-80. http://dx.doi.org/10.1080/02732170701675201

Chan, W.W., \& Lam, J.C. (2002). Prediction of pollutant emission through electricity consumption by the hotel industry in Hong Kong. International Journal of Hospitality Management, 21(4), 381-391. http://dx.doi.org/10.1016/S02784319(02)00027-0

Cross, S. E., \& Madson, L. (1997). Models of the self: self-construals and gender. Psychological bulletin, 122(1), 5. http://dx.doi.org/10.1037/0033-2909.122.1.5 
Dagher, G. K., \& Itani, O. (2014). Factors influencing green purchasing behaviour: Empirical evidence from the Lebanese consumers. Journal of Consumer Behaviour, 13(3), 188-195. http://dx.doi.org/10.1002/cb.1482

Dagher, G. \& Itani, O. (2012). The influence of environmental attitude, environmental concern and social influence on green purchasing behavior. Review of Business Research, 12 (2),104-111.

Davidson, D., \& Freudenburg, W. (1996). Gender and environmental risk concerns: a review and analysis of available research. Environment and Behavior, 28(3), 302-339. http://dx.doi.org/10.1177/0013916596283003

De Pelsmacker, P., Driesen, L., \& Rayp, G. (2005). Do consumers care about ethics? Willingness to pay for fair-trade coffee. Journal of consumer affairs, 39(2), 363385. http://dx.doi.org/ 10.1111/j.1745-6606.2005.00019.x

Deng, J.,Walker, G.J., \& Swinnerton, G. (2006). A comparison of environmental values and attitudes between Chinese in Canada and Anglo-Canadians. $\begin{array}{llll}\text { Environment } \quad \text { and } & \text { Behavior, }\end{array}$ http://dx.doi.org/10.1177/0013916505278458

Do Paço, A., \& Raposo, M. (2009). "Green" segmentation: an application to the Portuguese consumer market. Marketing Intelligence \& Planning, 27(3), 364-379. http://dx.doi.org/10.1108/02634500910955245

Diamantopoulos, A., Schlegelmilch, B. B., Sinkovics, R. R., \& Bohlen, G. M. (2003). Can socio-demographics still play a role in profiling green consumers? A review of the evidence and an empirical investigation. Journal of Business Research, 56(6), 465-480. http://dx.doi.org/10.1016/S0148-2963(01)00241-7

Dietz, T., Kalof, L., \& Stern, P. C. (2002). Gender, values, and environmentalism. Social Science Quarterly, 83(1), 353-364. http://dx.doi.org/10.1111/1540-6237.00088

D'Souza, C. (2004). Ecolabel programmes: a stakeholder (consumer) perspective. Corporate Communications: An International Journal, 9(3), 179-188. http://dx.doi.org/10.1108/13563280410551105

Dunlap, R. E., Van Liere, K. D., Mertig, A. G., \& Jones, R. E. (2000). New trends in measuring environmental attitudes: measuring endorsement of the new ecological paradigm: a revised NEP scale. Journal of social issues, 56(3), 425-442. http://dx.doi.org/10.1111/0022-4537.00176

Eagly, A. H. (2013). Sex differences in social behavior: A social-role interpretation. Psychology Press. 
Eisler, A. D., Eisler, H., \& Yoshida, M. (2003). Perception of human ecology: crosscultural and gender comparisons. Journal of Environmental Psychology, 23(1), 89-101. http://dx.doi.org/10.1016/S0272-4944(02)00083-X

Follows, S. B., \& Jobber, D. (2000). Environmentally responsible purchase behaviour: a test of a consumer model. European Journal of Marketing, 34(5/6), 723-746. http://dx.doi.org/10.1108/03090560010322009

Fisher, C., Bashyal, S., \& Bachman, B. (2012). Demographic impacts on environmentally friendly purchase behaviors. Journal of Targeting, Measurement and Analysis for Marketing, 20(3), 172-184. http://dx.doi.org/10.1057/jt.2012.13

Gurau, C., \& Ranchhod, A. (2005). International green marketing: a comparative study of British and Romanian firms. International Marketing Review, 22(5), 547-561. http://dx.doi.org/10.1108/02651330510624381

Han, H., Hsu, L. T. J., \& Lee, J. S. (2009). Empirical investigation of the roles of attitudes toward green behaviors, overall image, gender, and age in hotel customers' eco-friendly decision-making process. International Journal of Hospitality Management, 28(4), 519-528. http://dx.doi.org/10.1016/j.ijhm.2009.02.004

Han, H., Hsu, L. T. J., Lee, J. S., \& Sheu, C. (2011). Are lodging customers ready to go green? An examination of attitudes, demographics, and eco-friendly intentions. International Journal of Hospitality Management, 30(2), 345-355. http://dx.doi.org/10.1016/j.ijhm.2010.07.008

Hair, J., Anderson, R., Tatham, R., \& Black, W. (1998). Multivariate Data Analysis. Prentice Hall, Inc., Upper Saddle River, NJ.

Hayes, B. C. (2001). Gender, scientific knowledge, and attitudes toward the environment: A cross-national analysis. Political Research Quarterly, 54(3), 657-671. http://dx.doi.org/10.1177/106591290105400309

Hughes, M., \& Tuch, S. A. (2003). Gender differences in whites' racial attitudes: Are women's attitudes really more favorable? Social psychology quarterly, 66(4), 384-401.

Hutchings, K., \& D. Weir. (2006). Guanxi and wasta: A comparison. Thunderbird International Business Review, 48(1), 141-156. http://dx.doi.org/10.1002/tie.20090

José Chiappetta Jabbour, C. (2010). Greening of business schools: a systemic view. International Journal of Sustainability in Higher Education, 11(1), 49-60. http://dx.doi.org/10.1108/14676371011010048 
Jain, S.K., \& Kaur, G. (2004). Green marketing: An attitudinal and behavioural analysis of Indian consumer. Global Business Review, 5(2), 187-205. http://dx.doi.org/10.1177/097215090400500203

Jamali, D., Sidani, Y., \& Safieddine, A. (2005). Constraints facing working women in Lebanon: An insider view. Women in Management Review, 20(8), 581-594. http://dx.doi.org/10.1108/09649420510635213

Kalafatis, S.P., Pollard, M., East, R., \& Tsogas, M.H. (1999). Green marketing and Ajzen's theory of planned behavior: a cross-market examination. Journal of $\begin{array}{llll}\text { Consumer } & \text { Marketing, } & 16 & \text { (5), 441-460. }\end{array}$ http://dx.doi.org/10.1108/07363769910289550

Kasturi, C. S. (2011). Education options past generations never had. The Hindustan Times, 10(23), 14.

Kausar, Z. (1995). Women in feminism and politic [s]: new directions towards Islamization. Women's Affairs Secretariat (WAFA), IIUM.

Kauser, S., \& Tlaiss, H (2011). The arab women manager: participation, barriers, and future prospects. Journal of International Business and Economy, 12(1), 35-56.

Khattab, H. (1996). The Muslim woman's handbook. London: TA-HA Publishers.

Kim, Y., \& Choi, S. M. (2005). Antecedents of green purchase behavior: An examination of collectivism, environmental concern, and PCE. Advances in Consumer Research, 32, 592.

Kinnear, T.C., Taylor, J.R., \& Ahmed, S.A. (1974). Ecologically concerned consumers: Who are they? Journal of Marketing, 38, 20-24.

Konrad, A. M., Ritchie Jr, J. E., Lieb, P., \& Corrigall, E. (2000). Sex differences and similarities in job attribute preferences: a meta-analysis. Psychological bulletin, 126(4), 593-641. http://dx.doi.org/10.1037/0033-2909.126.4.593

Kotchen, M. J., \& Reiling, S. D. (2000). Environmental attitudes, motivations, and contingent valuation of nonuse values: a case study involving endangered species. Ecological Economics, 32(1), 93-107. http://dx.doi.org/10.1016/S09218009(99)00069-5

Laroche, M., Bergeron, J., \& Barbaro-Forleo, G. (2001). Targeting consumers who are willing to pay more for environmentally friendly products. Journal of Consumer Marketing 18(6), 503-520. http://dx.doi.org/10.1108/EUM0000000006155

Lee, K. (2009). Gender Differences in Hong Kong Adolescent Consumers' Green Purchasing Behavior. Journal of Consumer Marketing, 26(2), 87-96. http://dx.doi.org/10.1108/07363760910940456 
Leonidou, L. C., Leonidou, C. N., \& Kvasova, O. (2010). Antecedents and outcomes of consumer environmentally friendly attitudes and behaviour. Journal of Marketing Management, 26(13-14), 1319-1344. http://dx.doi.org/10.1080/0267257X.2010.523710

Lim, W. M., Ting, D. H., Ng, W. K., Chin, J. H., \& Boo, W. X. A. (2013). Why Green Products remain unfavorable despite being labeled environmentally-friendly? Contemporary Management Research, 9(1), 35-46. http://dx.doi.org/10.7903/cmr-10209

Ling-yee, L . (1997). Effect of collectivist orientation and ecological attitude on actual environmental commitment: The moderating role of consumer demographics and product involvement . Journal of International Consumer Marketing, 9(4), 31-53. http://dx.doi.org/10.1300/J046v09n04_03

Loureiro, M. L., McCluskey, J. J., \& Mittelhammer, R. C. (2002). Will Consumers Pay a Premium for Eco-labeled Apples? Journal of Consumer Affairs, 36(2), 203-219. http://dx.doi.org/10.1111/j.1745-6606.2002.tb00430.x

Manakotla, K., \& Jauhari, V. (2007). Exploring consumer attitude and behavior towards green practices in the lodging industry in India. International Journal of Contemporary Hospitality Management, 19 (5), 364-377. http://dx.doi.org/10.1108/09596110710757534

Makeower, J. (2009) Strategies for the Green Economy: Opportunities and Challenges in the New World of Business . New York: McGraw-Hill. McEachern, M., \& McClean, P. (2002) Organic purchasing motivations and attitudes: are they ethical? International Journal of Consumer Studies, 26(2), 8592. http://dx.doi.org/10.1046/j.1470-6431.2002.00199.x

McIntyre, R.P., Meloche, M.S., \& Lewis, S.L., (1993). National culture as a macro tool for environmental sensitivity segmentation. AMA Educators Proceedings, 4, 153-159

McKeen, C.A., \& Burke, R.J. (1990), McKeen, C. A., \& Burke, R. J. (1990). Work experience and career success of managerial and professional women. University.

Melillo, W., Miller, S., \& Solman, G. (2006). Companies find it's not easy marketing green. Brandweek, 47(8), 26-27.

Metle, M. A. K. (2002). The influence of traditional culture on attitudes towards work among Kuwaiti women employees in the public sector. Women in Management Review, 17(6), 245-261. http://dx.doi.org/10.1108/09649420210441905 
MENA (Middle East and North Africa) (2007). Gender overview. Washington D.C.: The World Bank.

Merchant, C. (1979) The Death of Nature: Women, Ecology, and the Scientific Revolution. Harper \& Row, New York.

Milfont, L., \& Duckitt, J. (2004). The structure of environmental attitudes: a first-and second-order confirmatory factor analysis. Journal of Environmental Psychology, 24(3), 289-303. http://dx.doi.org/10.1016/j.jenvp.2004.09.001

Mobley, C., \& Kilbourne, W. (2013). Gender Differences in Pro-Environmental Intentions: A Cross National Perspective on the Influence of Self-Enhancement Values and Views on Technology. Sociological Inquiry, 83(2), 310-332. http://dx.doi.org/10.1111/j.1475-682X.2012.00431.x

Mohai, P. (1992) Men, women, and the environment: an examination of the gender gap in environmental concern and activism. Society and Natural Resources, 5(1), 1-19. http://dx.doi.org/10.1080/08941929209380772

Moisander J. (2001). Representation of Green Consumerism: A Constructionist Critique. Helsinki School of Economics and Business Administration: Helsinki.

Mostafa, M.M. (2007). Gender differences in Egyptian consumers' green purchase behavior: the effects of environmental knowledge, concern and attitude. International Journal of Consumer Studies, 31(3), 220-229. http://dx.doi.org/10.1111/j.1470-6431.2006.00523.x

Nath, V., Kumar, R., Agrawal, R., Gautam, A., \& Sharma, V. (2013). Consumer adoption of green products: Modeling the enablers. Global Business Review, 14(3), 453-470. http://dx.doi.org/10.1177/0972150913496864

Neal, M., Finlay, J., \& Tansey, R. (2005). "My father knows the minister" A comparative study of Arab women's attitudes towards leadership authority. Women in management review, 20(7), 478-497. http://dx.doi.org/10.1108/09649420510624729

Orabi, A. (1999). Arab women: Tradition and identity. In S. Mariam, editor, Liberation of Arab Women. Beirut: Arab Future Book Series.

Pettus, K. (1997). Ecofeminist citizenship. Hypatia, 12(4), 132-155. http://dx.doi.org/10.1111/j.1527-2001.1997.tb00301.x

Pizam, A. (2009). Green hotels: A fad, ploy or fact of life? International Journal of Hospitality Management, 28(1), 1.

Powell, G. N. and L. M. Graves. (2003). Women and men in Management. London: Sage Publications. 
Roberts, J.A. (1996). Green consumers in the 1990s: Profile and implications for advertising. Journal of Business Research, 36(3), 217-231. http://dx.doi.org/10.1016/0148-2963(95)00150-6

Riechard, D. \& Peterson, S. (1998). Perception of environmental risk related to gender, community socioeconomic setting, age, and locus of control. Journal of Environmental Education, 30(1), 11-19. http://dx.doi.org/10.1080/00958969809601858

Schahn, J., \& Holzer, E. (1990). Studies of Individual Environmental Concern The Role of Knowledge, Gender, and Background Variables. Environment and Behavior, 22(6), 767-786. http://dx.doi.org/10.1177/0013916590226003

Schultz, P. (2000) Empathizing with nature: the effects of perspective taking on concern for environmental issues. Journal of Social Issues, 56(3), 391-406. http://dx.doi.org/ 10.1111/0022-4537.00174

Schwartz, S. H. (1992). Universals in the content and structure of values: Theoretical advances and empirical tests in 20 countries. Advances in experimental social psychology, 25(1), 1-65.

Seguin, C., Pelletier, L., \& Hunsley, J. (1998). Toward a model of environmental activism. Environment and Behavior, 30(5), 628-652. http://dx.doi.org/10.1177/001391659803000503

Sidani, Y. (2005). Women, work, and Islam in Arab Societies. Women in Management Review, 20(7), 498-512. http://dx.doi.org/10.1108/09649420510624738

Smith, S., Haugtvedt, C., \& Petty, R. (1994) Attitudes and recycling: does the measurement of affect enhance behavioral prediction? Psychology and Marketing, 11(4), 359-374. http://dx.doi.org/10.1002/mar.4220110405

Snelgar, R.S. (2006). Egoistic, altruistic, and biospheric environmental concerns: Measurement and structure. Journal of Environmental Psychology, 26(2), 87-99.

Soonthonsmai, V. (2007). Environmental or green marketing as global competitive edge: Concept, synthesis, and implication. In EABR (Business) and ETLC (Teaching) Conference Proceeding, Venice, Italy.

Steel, B.S. (1996). Thinking globally and acting locally? Environmental attitudes, behavior, and activism. Journal of Environmental Management, 47(1), 27-36. http://dx.doi.org/10.1006/jema.1996.0033

Stern, P., \& Dietz, T. (1994). The value basis of environmental concern. Journal of Social Issues, 50(3), 65-84 http://dx.doi.org/10.1111/j.1540-4560.1994.tb02420.x 
Stern, P.C., Dietz, T., \& Kalof, L. (2005). Value orientations, gender and environmental concern. in Kalof, L. and Satterfield, T. (Eds), The Earthscan Reader in Environmental Values, Earthscan, London, Sterling, 188-206.

Tarrant, M.A., \& Cordell, H.K. (1997). The effect of respondent characteristics on general environmental attitude-behavior correspondence. Environment and behavior, 29(5), 618-637 http://dx.doi.org/10.1177/0013916597295002

Thompson, S., \& Barton, M. (1994). Ecocentric and anthropocentric attitudes toward the environment. Journal of Environmental Psychology, 14(2), 149-157.

Tikka, P. M., Kuitunen, M. T., \& Tynys, S. M. (2000). Effects of educational background on students' attitudes, activity levels, and knowledge concerning the environment. The journal of environmental education, 31(3), 12-19. http://dx.doi.org/10.1080/00958960009598640

Tlaiss, H., \& Kauser, S. (2011).The impact of gender, family and work on the career advancement of Lebanese women. Gender in Management: An International Journal, 26 (1), 8-36 http://dx.doi.org/10.1108/17542411111109291

Tlaiss, H., \& S. Kauser. (2010). Perceived organizational barriers to women "s career advancement in Lebanon. Gender in Management: An International Journal, 25 (6), 462-496. http://dx.doi.org/10.1108/17542411011069882

Van Liere, K.D., \& Dunlap, R.E. (1981). Environmental concern: Does it make a difference how it's measured? Environment and Behavior, 13(6), 651-676. http://dx.doi.org/10.1177/0013916581136001

Vazifehdoust, H., Taleghani, M., Esmaeilpour, F., \& Nazari, K. (2013). Purchasing green to become greener: Factors influence consumers' green purchasing behavior. Management Science Letters, 3(9), 2489-2500. http://dx.doi.org/10.5267/j.msl.2013.08.013

Wahid, N. A., Rahbar, E., \& Shyan, T. S. (2011). Factors influencing the green purchase behavior of Penang environmental volunteers. International Business Management, 5(1), 38-49. http://dx.doi.org/10.3923/ibm.2011.38.49

Walker, J. (2000), Environmental Ethics, British Council Library Cataloging and Data, London.

Wehrmeyer, W., \& McNeil, M. (2000). Activists, pragmatists, technophiles and treehuggers? Gender differences in employees' environmental attitudes. Journal of Business Ethics, 28, 211-222. http://dx.doi.org/10.1023/A:1006253212744

Weigel, R. H. (1983). Environmental attitudes and the prediction of behavior. Environmental psychology: Directions and perspectives, 257-287. 
West, C., \& Fenstermaker, S. (1995). Doing difference. Gender \& Society, 9(1), 8-37. http://dx.doi.org/10.1177/089124395009001002

Widegren, O. (1998). The new environmental paradigm and personal norms. $\begin{array}{llll}\text { Environment } \quad \text { and } & \text { Behavior, }\end{array}$ http://dx.doi.org/10.1177/0013916598301004

Williams, J.E., \& Best, D.L. (1990), Sex and Psyche: Gender and Self Viewed Crossculturally, Sage, Newbury Park, CA.

World Bank (2005). The status and progress of women in the Middle East and North Africa. World Bank Middle East and North Africa socio-economic development group. Washington D.C. World Bank Publications.

Wrong D. H. (1961). "The oversocialized conception of man in modern sociology". American Sociological Review, 26(2), 183-193.

Xiao, C., \& Hong, D. (2010). Gender differences in environmental behaviors in China. Population and Environment, 32(1), 88-104. http://dx.doi.org/10.1007/s11111-010-0115-z

Zelezny, L., \& Bailey, M. (2006). A call for women to lead a different environmental movement. Organization \& environment, 19(1), 103-109. http://dx.doi.org/10.1177/1086026605285588

Zelezny, L., Chua, P., \& Aldrich, C. (2000). Elaborating on gender differences in environmentalism. Journal of Social Issues, 56 (3), 443-57. http://dx.doi.org/10.1111/0022-4537.00177 
